\title{
CORRELATION OF CLINICAL PRESENTATIONS WITH ENDOMETRIAL PATHOLOGIES IN WOMEN PRESENTING WITH ABNORMAL UTERINE BLEEDING: A PROSPECTIVE DESCRIPTIVE STUDY
}

\author{
Basnet $P^{1^{*}}$, Thakur $A^{2}$, Agrawal $A^{2}$, Bhandari $S^{3}$, Sitaula $S^{3}$, Karki $S^{4}$
}

\section{Affiliation}

1. Associate Professor, Department of Obstetrics and Gynaecology, B. P. Koirala Institute of Health Science, Dharan

2. Additional Professor, Department of Obstetrics and Gynaecology, B. P. Koirala Institute of Health Science, Dharan

3. Assistant Professor, Department of Obstetrics and Gynaecology, B. P. Koirala Institute of Health Science, Dharan

4. Professor, Department of Pathology, BP Koirala Institute of Health Sciences

\section{ARTICLE INFO}

Article History

Received : 18 February, 2018

Accepted : 23 March, 2018

Published : 30 April, 2018

(C) Authors retain copyright and grant the journal right of first publication with the work simultaneously licensed under Creative Commons Attribution License CC - BY 4.0 that allows others to share the work with an acknowledgment of the work's authorship and initial publication in this journal.

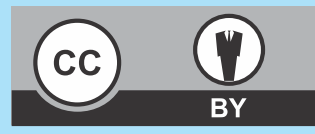

\section{ORA 55}

DOI: http://dx.doi.org/10.3126/bjhs.v3i1.19757

\section{* Corresponding Author}

Dr Pritha Basnet

Associate Professor

Department of Obstetrics and Gynecology

B. P. Koirala Institute of Health Science, Dharan

Email: prithapep@yahoo.com

https://orcid.org/0000-0001-7527-5365

\section{Citation}

Basnet P, Thakur A, Agrawal A, Bhandari S, Sitaula S, Karki S. Correlation of Clinical Presentations with Endometrial Pathologies in Women Presenting with Abnormal Uterine Bleeding. A Prospective Descriptive Study. BJHS 2018;3(1)5:354-356.

\section{ABSTRACT}

\section{Introduction}

Abnormal uterine bleeding (AUB) is one of the common presenting symptoms in women attending gynaecology outpatient department and has remained one of the most frequent indications for hysterectomy in developing countries. Endometrial sampling is used as the first diagnostic step in AUB.

\section{Objectives}

To correlate the clinical presentations with endometrial pathologies in women presenting with abnormal uterine bleeding.

\section{Methodology}

This was a hospital based descriptive study carried out on one hundred and nineteen women who presented with $A \cup B$ and planned for endometrial biopsy. Clinical profile of the patient was recorded and the histopathology of the sampled endometrial tissue was retrieved. Correlation of abnormal uterine bleeding with histopathology report was done using appropriate statistical test.

\section{Results}

The mean age of presentation of women with abnormal uterine bleeding was $46.56 \mathrm{yrs} \pm 9.525$. Irregular menstrual cycle was the commonest reason seeking treatment for AUB. The commonest histopathology among women who underwent endometrial biopsy was secretory endometrium $(39.5 \%)$. Other causes identified were proliferative endometrium (21.8\%), mucus flakes with hemorrhage (16\%), disordered proliferative endometrium (10\%), pill endometrium $(5 \%)$, endometritis $(5.9 \%)$, endometrial carcinoma (1.7\%),endometrial hyperplasia without atypia (1.7\%).

\section{Conclusion}

The nature of endometrial pathology is varied across the entire spectrum of women presenting with abnormal uterine bleeding. Knowledge of endometrial pathology helps in directing specific management and can provide better care to women presenting with abnormal uterine bleeding.

\section{KEYWORDS}

Abnormal uterine bleeding, endometrial biopsy, endometrial pathology 


\section{INTRODUCTION}

Abnormal uterine bleeding is one of the most common complaints seen in women presenting to gynecology out patient department. Normal menstruation is defined as "the bleeding from secretory endometrium associated with an ovulatory cycle, not exceeding a length of five days". Any bleeding not fulfilling these criteria is referred to as abnormal uterine bleeding. ${ }^{1}$ Bleeding is said to be abnormal when the pattern is irregular, abnormal duration (>7days) or menorrhagia or abnormal amount (>80 ml/menses). ${ }^{2}$ These are also expressed as menorrhagia, metrorrhagia, polymenorhoea and oligomenorrhoea. Abnormal uterine bleeding is caused by a numerous organic or non-organic causes. Evaluation of abnormal uterine bleeding is very important to know the benign nature of the lesion and to exclude carcinoma. This can be done by performing endometrial biopsy as an office procedure. Histopathological examination of endometrial sample remains the gold standard for diagnosis of endometrial pathology. ${ }^{3}$ The aim of this study was to know the varied presentation of abnormal uterine bleeding along with the histopathological diagnosis so that optimal treatment can be provided to the patient.

\section{METHODOLOGY}

This hospital based prospective descriptive study was carried in the department of Obstetrics and Gynecology, BPKIHS, Dharan in collaboration with the Department of pathology over a period of one year from February 2017 till January 2018. All women with abnormal uterine bleeding who were posted for endometrial biopsy as decided by treating doctor were recruited in the study. The study was started after obtaining ethical clearance from the Institutional Ethical Review Committee.

Written Informed consent was taken before the procedure. Pregnancy presenting as abnormal uterine bleeding, women with medical disorder (requiring anticoagulant, bleeding disorder) and women who underwent hysterectomy for abnormal uterine bleeding were excluded from the study. Clinical details of the patient was recorded along with the ultrasonography findings and entered in the proforma. The office endometrial biopsied tissue was sent to pathology lab fixed in $10 \%$ formalin for histopathological examination and the report was collected from the pathology department. The sample size was calculated to give the study $80 \%$ power considering $95 \%$ confidence interval with the level of significance being $5 \%$. The prevalence of AUB was taken to be $25 \%$ according to the study done by Abid M etal. ${ }^{4}$ The data collected was entered in Microsoft Excel and anaysed by SPSS 11.5 version. For descriptive statistics percentage, mean, standard deviation, interquartile range was calculated. Chi-square test was used for categorical variable.

\section{RESULTS}

Heavy menstrual flow was the commonest symptom seeking treatment for abnormal uterine bleeding. Dysmenorrhea was seen in only $17.6 \%$ (21/119) of the women with abnormal uterine bleeding. The various endometrial pathologies is described in table 2. Secretory endometrium was the most common endometrial pathology seen. The entire spectrum of women with abnormal uterine bleeding as described in table 3 . The pattern of abnormal uterine bleeding was not statistically significant with the endometrial pathology. Other associated findings in these women were adnexal cyst (8.4\%), cervical polyp seen in $4.2 \%$ and fibroid uterus was seen in $10.9 \%$ of the women presenting with abnormal uterine bleeding.

\begin{tabular}{|lc|}
$\begin{array}{l}\text { Table 1: Menstrual Pattern } \\
\text { Type }\end{array}$ & $\begin{array}{c}\mathrm{N}=119) \\
\text { Percentage }\end{array}$ \\
\hline Menorrhagia & $36.1 \%$ \\
\hline Metrorrhagia & $35.3 \%$ \\
\hline Post-menopausal bleeding & $16 \%$ \\
\hline Menometrorrhagia & $11.8 \%$ \\
\hline Polymenorrhoea & $0.8 \%$ \\
\hline
\end{tabular}

Table 2: Endometrial Pathology ( $\mathrm{N}=119)$ Type Percentage

\begin{tabular}{ll} 
Secretory endometrium & 39.5 \\
\hline Proliferative endometrium & 21.8 \\
\hline Mucus flakes with hemorrhage & $14 \%$ \\
\hline Disordered Proliferative endometrium & 10.9 \\
\hline Endometritis & 5.9 \\
\hline Pill Endometrium & 4.2 \\
\hline Endometrial carcinoma & 1.7 \\
\hline Endometrial hyperplasia without atypia & 1.7
\end{tabular}

Table 3: Endometrial pathology according to menstrual pattern

\begin{tabular}{|l|c|r|r|}
\hline & menorrhagia & metrorrhagia & $\begin{array}{l}\text { postmeno- } \\
\text { pausal } \\
\text { bleeding }\end{array}$ \\
\hline Proliferative & $23.3 \%$ & $26.3 \%$ & $5.3 \%$ \\
\hline Secretory & $48.8 \%$ & $40.4 \%$ & $15.8 \%$ \\
\hline $\begin{array}{l}\text { Endometrial } \\
\text { hyperplasia }\end{array}$ & - & - & $10.5 \%$ \\
\hline $\begin{array}{l}\text { Endometritis } \\
\text { Mucus flakes with }\end{array}$ & $4.7 \%$ & $7 \%$ & $5.3 \%$ \\
\hline $\begin{array}{l}\text { hemorrhage } \\
\text { Disorered Proliferative }\end{array}$ & $11.6 \%$ & $12.3 \%$ & $24.3 \%$ \\
\hline $\begin{array}{l}\text { endometrium } \\
\text { Pill endometrium }\end{array}$ & $4.7 \%$ & $5.3 \%$ & - \\
\hline $\begin{array}{l}\text { Endometrial } \\
\text { malignancy }\end{array}$ & - & - & $10.5 \%$ \\
\hline
\end{tabular}

$P$ value 0.077 NS. 


\section{DISCUSSION}

Endometrial diseases rank among the most common gynecological disorders that affect women globally. ${ }^{5}$ The commonest age presenting with AUB was $41-50$ years in our study (43.69\%). A study by Khadim et al, of the 101 patients, $56(55.40 \%)$ were in the reproductive age group between $18-39$ years, $33(32.70 \%)$ were in the perimenopausal age group between $40-50$ years, and $12(11.90 \%)$ were in the postmenopausal age group $>51$ years. ${ }^{5}$ Perimenopause is defined by the World Health Organization as the 2-8 years preceding menopause and 1 year after the final menses. ${ }^{6}$ As women approach menopause, cycles shorten and often become intermittently anovulatory due to a decline in the number of ovarian follicles and fluctuations in the estradiol level leading to various patterns of abnormal bleeding. ${ }^{7}$

In this study the bleeding pattern ranged from menorrhagia to postmenopausal bleeding with most of the patients presenting with menorrhagia $(36.1 \%)$ followed by metrorrhagia (35.3\%). Study done by khadim et al showed the most common presenting complaint was menorrhagia (48.86\%) followed by post-menopausal bleeding (26.05\%). ${ }^{5}$ Secretory endometrium was the most common endometrial pathology seen in the study group. In a study done by $\mathrm{R}$ Khan etal endometrial hyperplasia $(20.5 \%)$ was the most common endometrial pathology followed by luteal phase insufficiency (15.6\%) and secretory endometrium (13.7\%). ${ }^{8}$ Another study by Rajshree et al showed secretory endometrial pathology in only $7.95 \%$ of the cases. ${ }^{3}$ This could be due to variation in the age group of the study population presenting with abnormal uterine bleeding due to diverse geographical location, socio economic condition, life style factors including obesity and medical conditions like diabetes mellitus.

Disordered proliferative endometrium is an exaggeration of the normal proliferative phase without significant increase in the overall ratio of glands to stroma and is due to persistent estrogen stimulation., ${ }^{7,9}$ Our study showed disordered proliferative endometrium to be present in $10.9 \%$ of the cases. Jetley etal reported disordered proliferative endometrium in $6.8 \%$ of the cases. ${ }^{10}$ Most of the histopathological report showed benign nature of the lesion with endometrial malignancy seen only in $1.7 \%$ of the cases. Similar results were also reported in study done by Rajshree etal (2.52\%).

\section{CONCLUSION}

The nature of endometrial pathology was varied across the entire spectrum of women presenting with abnormal uterine bleeding. Knowledge of endometrial pathology helps in directing specific management and can provide better care to women presenting with abnormal uterine bleeding.

\section{RECOMMENDATION}

Endometrial evaluation by histopathology is an important diagnostic tool in women presenting with abnormal uterine bleeding with definite role in perimenopausal and postmenopausal age group.

\section{LIMITATION OF THE STUDY}

The sample size could have been larger to include more proportion of women with abnormal endometrial pathology including malignancy.

\section{ACKNOWLEDGEMENT}

I would like to acknowledge all my patients and department of Obstetrics and Gynaecology for their support in conducting the research.

\section{CONFLICT OF INTEREST}

The author has no conflict of interest.

\section{REFERENCES}

1. Rosai J. Female reproductive system - Uterus - corpus. In: Rosai J Ed. Rosai and Ackerman's surgical pathology 9th Ed. New Delhi: Elsevier, A division of Reed Elsevier, India Private limited; 2004 (2).1569-635.

2. Speroff L, Fritz MA. Menopause and the peri-menopausal transition. In: Clinical gynaecologic endocrinology and infertility. 7th edition. Jaypee Brothers Med Publishers (P) Ltd. 2005: 621-88.

3. Rajshree P. Damle. Clinicopathological Spectrum of Endometrial Changes in Peri-menopausal and Post-menopausal Abnormal Uterine Bleeding. Journal of Clinical and Diagnostic Research. 2013 7(12): 2774-2776. PMID: 24551634.

4. Abid M, Hashmi AA, Malik B, Haroon S, Faridi N, Edhi MM, Khan M. Clinical pattern and spectrum of endometrial pathologies in patients with abnormal uterine bleeding in Pakistan: need to adopt a more conservative approach to treatment.BMC Women's Health2014 14:132. PMID:25370003.

5. Khadim MT, Zehra T, Ashraf HM. Morphological study of Pipelle biopsy specimens in cases of abnormal uterine bleeding. J Pak Med Assoc. 2015;65(7).

6. Goldstein SR. Menorrhagia and abnormal bleeding before the menopause. Best Pract Res Clin Obstet Gynaecol 2004; 18:59-69. PMID: 15123058.

7. Majur MT, Kurman RJ. Normal endometrium and infertility evaluation. In: Mazur MT, Kurman RJ, editors. Diagnosis of endometrial biopsies and curettings: A practical approach. 2nd ed. New York: Springer Verlag; 2005. p. 7-33.

8. R Khan, RK Sherwani, S Rana, S Hakim, ZS Jairajpuri. ClincoPathological Patterns in Women with Dysfunctional Uterine Bleeding. Iran 2016 winter; 11(1):20-6. PMID:26870139.

9. Mutter GL. Diagnosis of premalignant endometrial disease. J ClinPathol 2002; 55:326-31. PMID: 11986334.

10. Jetley S, Rana S, Jairajpuri ZS. Morphological spectrum of endometrial pathology in Middle-aged women with atypical uterine bleeding: A study of 219 cases. J Midlife Health Health. 2013; 4(4): 216-220. Doi:10.4103/0976-7800.122242. 